\title{
DOUBLE MUSCling IN CATTLE AND MALIGNANT HYPERTHERMiA IN PIGS \\ COMMON FEATURES
}

W. A. King and L. Ollivier. - Department of Animal Genetics Nutrition and Hygiene, Royal Veterinary College, S-750 o7 Uppsala 7, Sweden and Station de Génétique quantitative et appliquée Centre National de Recherches Zootechniques, I.N.R.A., 78350 Jouy-en-Josas, France.

Double Muscling (Hereditary Muscular Hypertrophy) is an inherited condition resulting from hyperplasia and hypertrophy of muscle fibe1s in beef breeds of cattle. Comparative histological and ultrastructural studies of both normal and affected cattle have indicated that the most consistent feature of this syndrome is a disruption of the sarcolemma and other membrane components of the muscle. Osmotic response tests on erythrocytes revealed that erythrocytes from double muscled cattle were more sensitive to osmotic shock and have suggested that the cell membrane defect is not specific to muscle cells. Muscle biopsy cultures of normal and double muscled adults, which revealed that more rapid in vitro muscle differentiation occurred in the latter than those of normal, have suggested that the cell membrane defect is a primary rather than a secondary lesion.

A condition of stress susceptibility (Malignant Hyperthermia) which exists in heavily muscled pigs, bears close resemblance at the histological and ultrastructural level to double muscling syndrome in cattle. When exposed to halothane anesthetic, affected pigs exhibit gross muscular rigidity, rapid rise in body temperature, accelerated pulke, hyperventilation, blotchy cyanosis, metabolic acidosis and rapid rise in concentration of serum electrolytes. Osmotic response tests conducted on erythrocytes collected from Belgian Landrace pigs which reacted positively and negatively to exposure to halothanc anesthetic revealed that increased osmotic fragility of erythrocytes is a consistent feature of the Malignant Hyperthermia syndrome.

THE EFFICIENCY OF MARKER SIRE USE IN A.I.

\section{J. Connolly, E. P. Cunningham. - Agricultuval Institute, Dublin, Ireland.}

Marker (or reference) sires are frcquently used to provide a link between A. I. testing centres, particularly where the sires being tested are used at only one centre. This paper examines the efficiency of various allocations of resources between sires on test and marker sires. The level of marker sire replication at centres is critical in determining the efficiency of comparisons between sires on test in different testing centres. Formules are derived giving the optimum level of replication that should be allocated to marker sires. The situation where there is some replication across centres of the sires on test is also discussed.

\section{Einfluss der Herdenleistungsniveau auf Nachkommenbullenprüifung}

E. Dymnicki, A. Rabek und R. Grabowski. - Institut für Genetik und Tievzucht der Polnischen Akademie für Wissenschaften in Jastrzebiec (Polen).

Es ist bekannt, dass genetische Varianz der Milchleistungsmerkmale vom Herdenniveau abhänging ist. Dabei taucht die Frage auf, ob man mit del gleichen Genauigkeit die Nachkommenbullenprüfung unabhängig vom Leistungsniveau führen kann. Diese Fragen wurden am Schwarzbunten - Material untersucht.

Die Untersuchungen wurden in Feld- und Stationsbedingungen durchgeführt. Auf der Station in Jastrzebiec wurden 8 Nachkommengruppen von Bullen, die schon früher als gleiche positive Vereber aber in unterschiedlichem Herdenniveau geprüft wurden untersucht. Von jedem Bull wurde I 2 Töchter gekauft. Der Unterschied zwischen Herdenniveau betrug etwa I ooo kg Milk ( 3 ooo und 4 ooo $\mathrm{kg}$ ). Auf der Station wollten wir diese Bullen noch einmal prüfen, um zu feststellen, ob das Herdenniveau im Feldprüfung (Stallgefährtinnenvergleichsmethode) eine Rolle speilt.

Ausser der diesen Untersuchung wurde auch eine Prüfung der selben Bullen in unterschiedlichen Herdenniveaus durchgeführt. Zur Verfügung standen etwa 5 ooo erste Laktationen. Die Klassengrenzen wurden entsptechend des jeweiligen Herdendurchschnittes bis $2800 \mathrm{~kg}$ $2800-3700 \mathrm{~kg}$ und über $3700 \mathrm{~kg}$ Milch festgelegt. Es wurden nur Nachkommen von KB-Bullen ausgewertet, die in jeder Klasse mindestens ro Töchter hatten. Insgesamt wurden 44 Bullen mit 2520 Töchter berücksichtigt. Die Zuchtwertschätzung wurde nach der angewandten in Polen Stallgefährtinnenvergleichsmethode durchgeführt. 
Die Ergebnisse zeigen, dass auf der Station die Fettleistungsunterschiede zwieschen den Nachkommengruppen der Bullen die in unterschiedlichen Herdenniveaus geprüft wurden, sind nicht signifikant. In der Felduntersuchung ist das nicht so klar. Die Reihenfolgen der Bullen in zwei ersten Nieveaustufen sind im Vergleich mit der Reihenfolge im "hochen" Nieveau weniger unterschiedlich. Rangkorelationskoeffizienten betragen : Insgesamt-Niedrig 0,78 , Insgesamt-Mittel 0,86 , Insgesamt-Hoch 0,65 , Niedrig-Mittel 0,68 , Niedrig-Hoch 0,55 , Mittel-Hoch 0,57 (Insgesamt $=$ Reihenfolge der Bullen ohne Berücksichtigung des Herdenniveau). Alle Koeffizienten sind statistisch signifikant. Diese Ergebnisse zeigen, dass keine gleiche Rangierung von KBBullen in verschiedenen Herdenniveaus auftreten muss. Man beobachtet aber, dass fast alle positiv geprüfte Bullen im niedriegem Niveau auch im hochem Niveau positive Zuchtwerte nachweisen. Die Verschiebung der Bullenrangierung auftritt am meistens innerhalb der positiv und negativ geprüften Bullen. 